\title{
ПЕРЕПИСКА В МЕССЕНДЖЕРЕ КАК ДОКАЗАТЕЛЬСТВО В ГРАЖДАНСКОМ СУДОПРОИЗВОДСТВЕ
}

\author{
(c) 2020 Шобей Лариса Геннадьевна
}

старший преподаватель кафедры финансов, финансового права, экономики и бухгалтерского учета Петрозаводский государственный университет, Россия, Петрозаводск

E-mail:1_shobey@mail.ru

\section{(c) 2020 Чернова Полина Андреевна \\ студент}

Петрозаводский государственный университет, Россия, Петрозаводск

член Молодежной палаты Консультативного совета при Управлении Роскомнадзора по Северо-Западному федеральному округу

E-mail:p_a_sh@mail.ru

В статье поднимается проблема представления электронной переписки как доказательства в гражданском судопроизводстве. Предлагаются способы установления подлинности электронных сообщений. Анализируется судебная практика, описывается опыт США в использовании электронных доказательств в судебном производстве. Обосновывается необходимость определения критериев допустимости электронных доказательств в гражданском производстве.

Ключевые слова: электронное сообщение, мессенджер, доказательство, идентификация личности, нотариальное действие, судебно-техническая экспертиза, судебная практика.

В настоящее время общение посредством использования сервиса обмена мгновенными сообщениями, т.е. мессенджеров, и социальных сетей стало неотъемлемой частью жизни общества. Разумеется, что информация, передаваемая в сообщениях через данные средства коммуникации, зачастую содержит важные сведения, на основе которых суд может установить наличие или отсутствие обстоятельств, имеющих значение для правильного рассмотрения и разрешения гражданского дела. В связи с этим, участникам гражданского судопроизводства необходимо знать, как придать юридическую силу электронной переписке. На сегодняшний день в законодательстве не существует определенного термина «электронное сообщение», который бы отразил все его существенные признаки и свойства как доказательства [13]. Положения пункта 10 статьи 2 Федерального закона от 27 июля 2006 г. N 149-Ф3 «Об информации, информационных технологиях и о защите информации» определили, что электронное сообщение - информация, переданная или полученная пользователем информационно-телекоммуникационной сети [2]. На сегодняшний день ни один нормативноправовой акт не разъясняет, какими характеристиками должна обладать электронная переписка, чтобы суд посчитал её допустимым доказательством.

В рамках определения письменных доказательств в статье 71 ГПК РФ содержится оборот «иные документы и материалы, выполненные в форме цифровой, графической записи, в том числе полученные посредством факсимильной, электронной или другой связи, с использованием информационно-телекоммуникационной сети «Интернет» [1]. Исходя из данных положений, можно сделать вывод, что электронные сообщения законодатель относит к письменным доказательствам. В связи с этим, поднимается вопрос не сколько о том, можно ли использовать такую переписку в качестве доказательств, а то, каким образом оформить данные доказательства.

Поскольку электронные доказательства относятся к письменным доказательствам, их необходимо преобразовать в материальный носитель информации, т.е. оформить в виде письменного бумажного документа. Самым простым способом является печать изображения с перепиской, иными словами скриншота переписки. В таком случае возникает вопрос об установлении достоверности, допустимости и относимости электронной переписки как доказательства. На сегодняшний день существует практика, свидетельствующая о том, что про- 
стой экземпляр распечатки переписки является надлежащим доказательством и не требует особого его представления [8].

Пленум Верховного суда РФ постановил, что «если иное не установлено законом или договором и не следует из обычая или практики, установившейся во взаимоотношениях сторон, юридически значимое сообщение может быть направлено, в том числе посредством электронной почты, когда можно достоверно установить, от кого исходило сообщение и кому оно адресовано» [4]. Стороны могут ссылаться на электронную переписку в процессе доказывания своей позиции, если она позволяет установить получателя, отправителя и содержание письма, а также получена законными способами, не противоречит основам гражданского процессуального законодательства. В частности, в судебной практике Второго арбитражного апелляционного суда имеется дело, по которому суд не признал электронную переписку надлежащим доказательством. Причиной данного обстоятельства служил тот факт, что идентифицировать лиц, осуществляющих электронную переписку, не представлялось возможным, поскольку при создании электронного почтового ящика не требуется представления документов, удостоверяющих личность физического лица, либо учредительных документов юридического лица [7].

Способом идентификации личностей получателя и отправителя электронных сообщений может являться договоренность между ними об использовании электронных писем в гражданско-правовом договоре и указанием в нем конкретных адресов электронной почты, идентифицирующих данных в мессенджерах, в частности, указанием номеров телефонов или уникальных логинов. Кроме этого, стороны могут сами придать электронной переписке юридическую силу, указав ряд условий о том, какой порядок признания доказательств стороны согласовали. Например, стороны могут указать условие, что простые распечатки (скриншоты) с мессенджеров подтверждают факт оказания услуг, выполнения работ, обмен документами, изменение ранее заключенного договора и другие юридически значимые действия.

Основываясь на российском законодательстве, можно определить несколько способов установления подлинности электронных сообщений. Стоит отметить, что в случае, если противоположная сторона отвергает достоверность предъявленного электронного сообщения, то подтверждение подлинности электронного сообщения обязательно для стороны, предъявившей его в качестве доказательства. Так, обеспечение электронного доказательства возможно произвести у нотариуса. По данным Федеральной нотариальной палаты, за семь месяцев 2020 года за фиксацией каких-либо электронных событий к нотариусам обратились более 13,5 тысячи человек. По итогам 2019 года спрос на данное нотариальное действие вырос на 12 процентов даже с учетом корректив, которые внес 2020 год [10]. Согласно ст. 102 и ст. 103 Основ законодательства Российской Федерации о нотариате нотариус в присутствии сторон и заинтересованных лиц осуществляет фиксацию информации, содержащейся в электронной переписке в мобильном приложении, путем оформления протокола осмотра информации на конкретном устройстве [3]. В данном протоколе нотариус удостоверяет наличие той информации, о которой было заявлено лицом, обратившимся к нему. Таковой может являться информация, содержащая конкретные цитаты, подробное описание изображений, аудио- и видеозаписей, сведения об устройстве связи (смартфон или компьютер), заверение, что абонентский номер принадлежит заявителю на основании договора с оператором связи. Скриншот переписки распечатывается и прикладывается к протоколу в качестве приложения. Однако стоит отметить, что нотариус не является экспертом в области компьютерной техники и не всегда может заметить подмену электронного адреса отправителя и прочих случаев недобросовестного поведения стороны, поэтому в некоторых случаях необходимо производство экспертизы [9]. Нотариус может подтвердить только факт переписки, а не личности получателя и отправителя [9]. Кроме этого, необходимо взять во внимание тот факт, что конкретные цитаты могут потерять смысл вне контекста, поэтому скриншот переписки в мессенджере должен быть содержательным. Данное обстоятельство подтверждает судебная практика. Так, при рассмотрении апелляционной жалобы Восьмой арбитражный апелляционный суд решал вопрос о допустимости электронной переписки. Суд указал, что из содержания переписки не следует, какие именно документы, кто и у кого запрашивал, какая ситуация является предметом переписки, поэтому признал переписку ненадлежащим доказательством [6]. В поста- 
новлении Второго арбитражного апелляционного суда отмечено: «В переписке отсутствуют реквизиты договоров, помещение не индивидуализировано, личность Олега не установлена», поэтому суд не счел данную переписку надлежащим доказательством [7]. Достаточная содержательность переписки напрямую влияет на ее признание судом относимым доказательством.

Для оформления всех официальных действий не обязательно прибегать к помощи нотариуса. Получение категоричного ответа относительно отсутствия фальсификации электронной переписки возможно только путем проведения экспертизы. Согласно статье 79 ГПК РФ суд может назначить экспертизу для установления юридической силы электронной переписки. Поскольку речь идет об электронной информации, которая хранится на компьютере или в сети «Интернет», то ее можно заверить при помощи специалиста с компьютерно-техническим профильным образованием. Эксперт сможет установить не только факт самой переписки, но и установить личности отправителя и получателя.

В практике Московского городского суда в 2018 г. было дело по иску о взыскании суммы аванса по договору подряда, компенсации морального вреда, штрафа, судебных расходов, оспаривалось выполнение работы в установленные договором сроки. В подтверждение своей позиции ответчик предоставил скриншоты сообщений в мессенджере WhatsApp. Суд посчитал, что данные скриншоты являются недопустимыми доказательствами в связи с отсутствием возможности установить отправителя сообщений; нотариально удостоверенный протокол осмотра электронной переписки в мобильном приложении не представлен; переписка в мессенджере WhatsApp противоречит пунктам спорного договора, в соответствии которым переписка между сторонами осуществляется путем направления корреспонденции заказными письмами с уведомлением [5]. Других доказательств суду ответчик не предоставил, поэтому суд удовлетворил требования истца.

В рамках статьи 188 ГПК РФ исследование доказательств может быть произведено на судебном заседании с участием специалиста. При этом суд может истребовать электронную переписку на техническом устройстве для обеспечения надлежащего качества консультации специалиста. Истребование документа на техническом носителе может создать сложность, однако позволит избежать предоставления недопустимых доказательств [11].

Наиболее показательным опытом использования электронных доказательств в судебном производстве является опыт Соединенных Штатов Америки. В данном государстве с конца 1960-х годов произошло появление в гражданском обороте электронно-вычислительных машин. Уже в 1975 году зарубежные законодатели приняли кодифицированный акт - Федеральные правила доказывания (Federal Rules of Evidence) - которые отнесли электронные документы к письменным доказательствам. В документе указывалось, что письменные документы состоят из букв, слов или цифр или их эквивалентов, выполненных от руки, на пишущей машинке, печатанием, фотографированием, магнитными импульсами, механическим или электронным записью или другим способом [12]. В октябре 2020 года в США Конференция Седона и ее рабочая группа по хранению и представлению электронных документов (Electronic Document Retention and Production) сообщили о публикации второй редакции документа «Комментарий Конференции Седона по доказательствам в виде сохраняемой электронным образом информации и их допустимости». Настоящая редакция содержит рекомендации, отражающие эволюцию технологий и поправки, внесённые в 2017 и 2019 годах в Федеральные правила доказывания [14]. Содержание комментария сводится к следующему. В первом его блоке отражено применение существующих правил прецедентного права к электронным доказательствам. Следующий блок представляют собой нормы о решении появляющихся проблем использования электронной информации в качестве доказательств. В частности, документ решает проблему идентификации лиц - установление владельца или создателя электронной информации. Третий блок включает в себя рекомендации по представлению, исследованию и оценке доказательств в судах. Стоит отметить, что детальная регламентация упрощает процесс признания электронных доказательств в деле допустимыми и способствует осуществлению защиты нарушенных прав, свобод и интересов граждан.

Таким образом, нужно отметить, что электронная переписка в мессенджерах и социальных сетях может являться доказательством в гражданском судопроизводстве, однако при 
этом должны быть соблюдены несколько требований. Электронная переписка должна позволять установить получателя, отправителя и содержание письма, а также должна быть получена законными способами, не должна противоречить основам гражданского процессуального законодательства. Анализируя судебную практику, можно сделать вывод, что юридическую силу электронным сообщениям могут придать согласованные сторонами условия договора, нотари- ус путем составления нотариального протокола, судебно-техническая экспертиза. Во избежание спорных ситуаций в контексте признания судом электронного доказательства допустимым, законодателю необходимо обозначить критерии допустимости и достоверности электронных доказательств или указать, какими способами можно идентифицировать получателя и отправителя и установить подлинность содержания электронной переписки.

\section{Библиографический список}

1. Гражданский процессуальный кодекс Российской Федерации: Федеральный закон от 14.11.2002 N 138-ФЗ// Собрание законодательства РФ. - 18.11.2002. - N 46. - ст. 4532.

2. Об информации, информационных технологиях и о защите информации: Федеральный закон от 27 июля 2006 г. N 149-ФЗ// Собрание законодательства РФ. - 31.07.2006. - N 31 (1 ч.). - ст. 3448.

3. Основы законодательства Российской Федерации о нотариате: утв. ВС РФ 11.02.1993 N 4462-1// Российская газета.-N 49. - 13.03.1993.

4. О применении судами некоторых положений раздела I части первой Гражданского кодекса Российской Федерации: Постановление Пленума Верховного Суда РФ от 23.06.2015 N 25// Российская газета. - N 140.30.06.2015.

5. Апелляционное определение Московского городского суда от 24.09.2018 по делу N 33-42376/2018

6. Постановление Восьмого арбитражного апелляционного суда от 17.01.2017 N 08АП-13836/2016 по делу N A81-1879/2016

7. Постановление Второго арбитражного апелляционного суда от 05.03.2018 N 02АП-606/2018 по делу N A29$9751 / 2017$

8. Постановление Девятого арбитражного апелляционного суда от 17.01.2012 N 09АП-34143/2011-ГК по делу N A40-65915/11-32-525

9. Захаренко В.В. Проблема представления электронного документа в качестве доказательства в гражданском и арбитражном процессах [Электр. ресурс]/ В.В.Захаренко// Вестник науки и образования.- Электрон. ст. - 2018. - URL: https://cyberleninka.ru/article/n/problema-predstavleniya-elektronnogo-dokumenta-vkachestve-dokazatelstva-v-grazhdanskom-i-arbitrazhnom-protsessah/viewer

10. Куликов В. Поймают на слове [Электр.ресурс]/ В.Куликов// Российская газета.- Электрон.ст. - № 193 (8247).- 30.08.2020.- URL: https://rg.ru/2020/08/30/rossiiane-nachali-fiksirovat-u-notariusov-perepisku-vtelefone.html

11. Попов В. А. Особенности исследования электронных документов и их применению в качестве доказательств в гражданском и арбитражном процессе [Электр. ресурс]/ Армия и общество. - Электрон. ст. - 2013. - URL: https://cyberleninka.ru/article/n/osobennosti-issledovaniya-elektronnyh-dokumentov-i-ih-primeneniyu-vkachestve-dokazatelstv-v-grazhdanskom-i-arbitrazhnom-protsesse/viewer

12. Правовая оценка электронных доказательств: иностранный опыт [Электр.pecypc]. - URL: http://www.s-quo. com/content/articles/337/7446/

13. Седельникова Д.В. Проблемы применения электронного доказательства в гражданском и арбитражном процессах/ Д. В. Седельникова [Электр. ресурс]// Правопорядок: история, теория, практика.- Электрон. ст.N 2 (13). - 2017. - URL: https://cyberleninka.ru/article/n/problemy-primeneniya-elektronnogo-dokazatelstva-vgrazhdanskom-i-arbitrazhnom-protsessah/viewer

14. Храмцовская Н. США: «Конференция Седона» опубликовала 2-ю редакцию «Комментария по доказательствам в виде сохраняемой электронным образом информации и их допустимости» [Электр.ресурс]/ H. Храмцовская. - URL: http://rusrim.blogspot.com/2020/10/2_30.html 